\title{
KOMUNITAS OLAHRAGA REMAJA DESA
}

\author{
Puji Ratno $^{1 *}$, Miftahul Ihsan², Budi Ali Mukmin ${ }^{3}$ \\ I*Jurusan Ilmu Keolahragaan, Fakultas Ilmu Keolahragaan, Universitas Negeri Medan, Medan, Indonesia \\ ${ }^{2}$ Jurusan Pendidikan Jasmani Kesehatan dan Rekreasi, Fakultas Ilmu Keolahragaan, Universitas Negeri Medan, \\ Medan, Indonesia \\ ${ }^{3}$ Jurusan Pendidikan Kewarganegaraan, Fakultas Ilmu Sosial, Universitas Negeri Medan, Medan, Indonesia \\ *Penulis Korespondensi: pujiratno@yahoo.com
}

\begin{abstract}
Abstrak
Tujuan dari kegiatan pengabdian masyarakat ini adalah untuk melaksanakan salah satu tridharma perguruan tinggi, khususnya bidang pengabdian kepada masyarakat untuk membantu mitra dalam menyelesaikan permasalahan yang dihadapinya, mulai dari aspek kesertaaan remaja dalam latihan pencak silat, program latihan, dan perlengkapan latihan. Target khusus dalam kegiatan ini dihasilkannnya perlengkapan latihan pencak silat yang standard nasional dalam pertandingan.metode yang digunakan untuk mencapai kegiatan ini adalah metode FGD, Penyuluhan dan sosialisasi bahaya penggunaan narkoba,Pembentukan komunitas olaharaga remaja desa,Pendampingan latihan olahraga bagi komunitas olahraga remaja desa Mitra dalam kegiatan pengabdian ini adalah perguaran silat garuda sakti dan Asslam. Jarak kedua mitra $\pm 20 \mathrm{~km}$ dari Universitas Negeri Medan dan dapat ditempuh dengan angkutan umum selama 30 menit. Komunitas pencak silat merupakan satu komunitas yang telah berdiri sejak tahun 2010 yang berada di desa Suka Makmur Kabupaten Deli Serdang. Akan tetapi dalam menjalankan program latihannya masih banyak mengalami kendala. Kesertaaan remaja dalam mengikuti latihan yang masih sedikit, metode melatih yang masih konvensional,pelatih tidak memiliki program latihan yang tertulis dan peralatan latihan yang belum memadai.Oleh karena itu diperlukan upaya yang konstruktif yang dapat mengatasi mengatasi permasalahan tersebut dengan kegiatan pelatuhan dan pendampingan. Kegiatan yang telah dilakukan adalah penyuluhan tentang bahaya narkoba bagi remaja, coching clinic bagi pelatih, pendampingan latihan karate, dan penyediaan peralatan latihan pencak silat.
\end{abstract}

Kata Kunci : Komunitas, Olahraga, Remaja.

\begin{abstract}
The purpose of this community service activity is to implement one of the Tri Dharma colleges, especially the field of community service to help partners in solving the problems they face, ranging from the aspect of teenagers in the practice of martial arts, exercise programs, and exercise equipment. Specific targets in this activity resulted in national standard pencak silat training equipment in the matches. Methods used to achieve this activity were FGD methods, extension and socialization of the hazards of drug use, Establishment of youth village teens, Assistance of sports exercises for youth community of village village Partners in this devotional activity is a silat garuda silat and Asslam silat. Distance of two partners $\pm 20 \mathrm{~km}$ from the State University of Medan and can be reached by public transport for 30 minutes. Pencak Silat community is a community that has been established since 2010 located in the village of Suka Makmur Deli Serdang Regency. However, in running the training program is still experiencing many obstacles. Teenagers' participation in training, conventional training methods, trainers do not have a written exercise program and inadequate training equipment. Therefore, constructive efforts are needed to overcome these problems with the accompaniment of accompaniment and accompaniment. Activities that have been done are counseling about the dangers of drugs for teenagers, coching clinic for trainers, karate training accompaniment, and the provision of training equipment pencak silat.
\end{abstract}

Keywords: Community, Sports, Youth

\section{PENDAHULUAN}

Generasi penerus bangsa adalah para remaja, yang diharapkan mampu untuk terus berkarya dalam rangka menjaga eksistensi bangsa Indonesia sebagai bangsa yang besar dan dihormati oleh bangsa-bangsa lain. Remaja sebagai generasi penerus tentu harus didik untuk dapat terus berinovasi, dan berkarya nyata bagi kebesaran bangsa Indonesia. Fakta saat ini 
menunjukkan bahwa tingkat kenakalan remaja sudah mencapai titik yang mencemaskan. (http://humas.polri.go.id, diakses tanggal 18 April 2017). Seks bebas dan tindak kriminal serta narkoba di kalangan siswa memang sudah memperihatinkan (http://polrespurbalingga.com, diakses tanggal 18 April 2017). Dari Januari hingga April, polisi telah meringkus empat anak di bawah umur yang bekerja sebagai kurir sabu. (http://humas.polri.go.id, diakses tanggal 18 April 2017).

Saat ini masyarakat digemparkan dengan pemberitaan pemerkosaan terhadap Yuyun (14) siswi kelas VIII SMP di Kecamatan Padang Ulak Tanding (PUT), Kabupaten Rejang Lebong, Provinsi Bengkulu yang diperkosa oleh 14 orang hingga tewas. Diantara ke 14 orang tersangka tersebut 7 orang anak masih di bawah umur, dan masih usia sekolah. Penyebab terjadinya peristiwa pemerkosaan dan diakhiri dengan pembunuhan oleh para tersangka ternyata adalah pornografi dan alkohol. Dimana sebelum melakukan tindakan itu para tersangka terlebih dahulu bersama-sama menonton konten pornografi dan meminum alkohol. Melihat data-data tersebut di atas, sebagian besar pelaku kejahatan tersebut adalah siswa SD, SLTP, dan SLTA.

Mencermati tingginya angka kenakalan remaja yang sangat tinggi tersebut, tentu harus dicari sebab utama permasalahannya, dan solusi agar tingkat kenakalan remaja semakin menurun.Ahmad Mawardi Anggota DPD RI Menyatakan bahwa, pemicu utama kenalan remaja adalah alkohol, miras, narkoba, dan internet yang tidak beretika (http://newsokezone.com, diakses tanggal 13 Mei 2016). Penyebab remaja mengkonsumsi alkohol, miras, narkoba, dan menonton konten pornografi melalui internet, adalah banyaknya waktu luang remaja yang tidak produktif sehingga mereka melakukan hal-hal yang negatif tersebut.

Solusi yang kemudian harus diberikan agar remaja tidak mengkonsumsi narkoba adalah memberikan pemahaman kepada orang tua dan remaja tentang bahaya dari penggunaan narkoba baik dari sisi kesehatan dan dari sisi hukum. Serta memberikan suatu kegiatan yang positif, agar waktu luang remaja lebih bermanfaat. Salah satu aktifitas yang sangat digemari oleh remaja adalah berolahraga, selain bermanfaat bagi pengembangan karakternya, juga dapat bermanfaat bagi perkembangan psikis dan fisiknya juga bermanfaat bagi masa depannya.

Kecamatan Deli Tua terdiri dari, Desa : 5, Kelurahan dengan luas wilayah 9,36 $\mathrm{Km}^{2}$, dengan jumlah penduduk sebanyak 56.691 jiwa. Batas wilayah Kecamatan Deli Tua sebelah barat adalah Kecamatan Namorambe, sebelah timur Kecamatan Patumbak, sebelah utara dengan kecamatan Medan Johor, dan sebelah selatan dengan kecamatan sibiru-biru. Kecamatan Deli tua merupakan daerah penyangga Kota Medan, dengan letak yang sangat strategis ini
Kecamatan deli tua termasuk Kecamatan yang sebagian besar penduduknya banyak bekerja di kota medan, sebagai buruh bangunan dan pegawai.

Desa Suka Makmur merupakan salah satu desa yang ada di Kecamatan Deli Tua yang hanya berjarak 3 kilometer dari pusat kota Kecamatan Deli tua dan 24 $\mathrm{Km}$ dari ibukota Kabupaten. Jumlah penduduk desa Suka Makmur yang berjumlah 5939 orang dengan 1544 kepala keluarga. Sumber mata pencaharian penduduk desa Suka Makmur mayoritas sebagai buruh sebanyak 503 orang penduduknya sebagai petani. Jumlah populasi remaja desa Suka Makmur usia 13-18 sebanyak 809 orang menjadi salah satu incaran bagi para pengedar narkoba yang ada di sekitar kecamatan Deli Tua. Berdasarkan informasi dari pihak kepolisisan, Jumlah pengedar narkoba yang pernah ditangkap oleh pihak kepolisian pada tahun 2015 yang berasal dari desa Suka Makmur ada 5 orang. Dan jumlah pengguna yang pernah ditangkap pada tahun 2015 sebanyak 18 orang. (data dari Polsek Patumbak).

Adanya pengedar dan pengguna narkoba yang ada dilingkungan masyarakat desa Suka Makmur ternyata berdampak pada sisi keamanan desa, berdasarkan hasil wawancara dengan salah satu pegawai kantor Kepala desa Suka Makmur bapak rendi, banyak warga yang melaporkan kehilangan harta bendanya, banyaknya anak remaja yang jarang pulang ke rumah. Maraknya tindak pencurian yang terjadi kemungkinan disebabkan oleh banyaknya remaja yang mengkonsumsi narkoba. Melihat data di atas tentunya kita semua harus melakukan tindakan yang dapat mencegah remaja dari penggunaan Narkoba. Tindakan pencegahan adalah suatu upaya yang sangat efektif dan efisien dalam rangka mengurangi menyebarnya pengunaan narkoba dikalangan remaja.

Mitra yang terlibat dalam kegiatan pengabdian masyarakat ini adalah Remaja Desa Suka Makmur yang tergabung dalam dua komunitas olahraga pencak silat, berdasarkan data yang telah dijelaskan di atas banyak permasalahan yang dihadapi oleh remaja desa suka makmur. Namun dalam kegiatan pengabdian ini kami hanya fokus pada permasalahan : Kurangnya pemahaman orang tua dan remaja terkait dampak buruk penggunaan narkoba. Belum optimalnya komunitas olahraga remaja desa dalam merekrut remaja desa untuk bergabung dalam kegiatan olahraga. Kurangnya sarana latihan pencak silat yang dapat digunakan oleh remaja. Tidak adanya pelatih yang dapat mendampingi remaja dalam beraktifitas olahraga. Dalam kegiatan ini solusi yang akan diberikan adalah : Memberikan pengarahan sosialisasi akan bahaya narkoba Mengoptimalkan peran komunitas olahraga remaja desa mensosialisaiskan kegiatan olahraga bagi remaja. Memberikan sarana latihan olahraga berupa body protector, samsak untuk tendangan dan target pukulan. Mendampingi komunitas remaja dalam berlatih olah raga. 
Melihat permasalahan yang ada, kami telah memberikan solusi untuk dimanfaatkan oleh pihak desa dan remaja dalam rangka melakukan upaya pencegahan penggunaan narkoba adalah. Memberikan kegiatan penyuluhan dengan melibatkan perangkat desa, orang tua, dan remaja. Keterlibatan perangkat desa, orang tua dan remaja dimaksudkan agar semua elemen masyarakat mengetahui dampak buruk penggunaan nakoba. Mengoptimalkan peran komunitas olahraga remaja desa, yang berfungsi sebagai wadah tempat menyalurkan hobi remaja, dan sebagai wadah untuk mengisi waktu luang bagi remaja desa. Memberikan sarana latihan olahraga pencak silat, hal ini di karenakan di desa Suka makmur terdapat perguruan Pencak Silat namun kendalanya fasilitas latihan yang kurang memadai seperti (body protector, dan foot protector sebagai alat pelindung yang digunakan dalam latihan spring antar pesilat), target pukulan yang hanya ada 2 dan ini sangat tidak memadai untuk digunakan oleh remja yang sedang berlatih. Memberikan pendampingan bagi komunitas olahraga yang ada, dengan bentuk melatih Pencak Silat

\section{BAHAN DAN METODE}

Berdasarkan permasalahan yang telah di kemukakan, maka dalam kegiatan ini metode pendekatan yang ditawarkan bagi realisasi program ini adalah model pemberdayaan dengan langkah-langkah sebagai berikut : 1) Tahap Persiapan, 2). Tahap Pelaksanaan (Implementasi) Program atau Kegiatan; dan 3) Tahap Pendampingan, 4). Tahap Evaluasi.

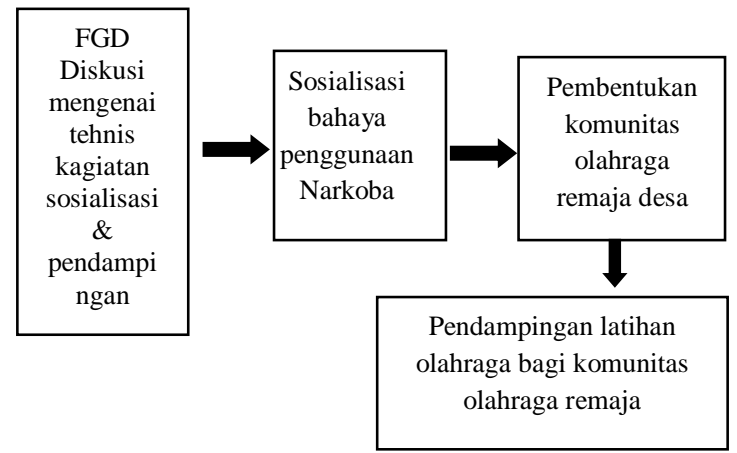

Gambar : Rancangan mekanisme kegiatan pengabdian

Pelaksanaan kegiatan akan dikoordinasikan dengan LPM-UNIMED dan tim mitra dan Instansi yang terkait seperti pengurusan surat izin, penyusunan jadwal kegiatan dan persiapan pengadaan fasilitas latihan yang akan diberikan kepada Tim Mitra. Tahapan persiapan (FGD), penyiapan sarana latihan olahraga. Setelah melakukan FGD tahapan berikutnya dalam kegiatan pengabdian masyarakat ini adalah melakukan kegiatan sosialisasi dan penyuluhan tentang bahaya penggunaan narkoba dengan mengundang seluruh perangkat desa, orang tua dan remaja.dengan menghadirkan narasumber dari tim pengabdi. Membentuk komunitas remaja desa yang diketahui oleh perangkat desa, serta memberikan bantuan sarana latihan olahraga bagi komunitas olahraga remaja desa.

Program pendampingan dalam kegiatan yang akan dilakukan bertujuan adalah untuk mendampingi komunitas olahraga remaja desa dalam melaksanakan latihan olahraga Pencak Silat. Adapun kegiatan pendampingan adalah sebagai berikut :Pendampingan penyusunan program latihan Pencak Silat, Pendampingan manajemen latihan olahraga Pencak Silat

Seluruh kegiatan pengabdian ini akan berjalan dengan baik, jika seluruh kegiatan didukung oleh Tim Mitra. Adapun rencana yang akan diterapkan untuk melibatkan Tim Mitra selama kegiatan adalah sebagai berikut :

a. Mengikuti seluruh kegiatan yang telah direncanakan dan disepakati bersama dengan sebaik-baiknya.

b. Menyampaikan dan memberikan informasi sejelas jelasnya yang menjadi permasalahan yang selama ini dihadapi sehingga dapat menjadi bahan pertimbangan dalam Pembuatan rencana kegiatan pengabdian.

Tahapan evaluasi ini dilakukan secara bertahap untuk mengukur tingkat keberhasilan dari kegiatan yang telah dilakukan. Indikator ketercapaian program adalah dengan terbentuknya komunitas olaharaga remaja desa, dan adanya kegiatan latihan olahraga bagi komunitas olehraga remaja desa.

Evaluasi pelaksanaan kegiatan secara khusus akan menjadi masukan yang akan ditindaklanjuti secara seksama di dalam perancangan kegiatan pengabdian kepada masyarakat secara multiyear. Kegiatan pengabdian multiyear yang dimaksud adalah Iptek bagi Desa

\section{HASIL DAN PEMBAHASAN}

Berdasarkan dari rencana kegiatan yang telah diajukan dalam proposal kegiatan pengabdian ini, telah terlaksana beberapa kegiatan yang telah dilakukan oleh tim pengabdi adapun kegiatan yang telah terlaksana adalah.

Survey awal untuk mengetahui situasi awal lokasi tempat pengabdian, dilakukan dengan observasi langsung pada tanggal 12 Juli 2017 ke lokasi kegiatan yaitu kantor desa Suka Makmur Kecamatan Deli Tua. Hal ini dilakukan sesuai dengan ketentuan Lembaga Pengabdian Kepada Masyarakat Unimed, bahwa setiap kegiatan pengabdian harus meminta izin pada pihak perangkat desa, dalam hal ini tim bertemu langsung dengan Bapak Suyatno selaku Kepala Desa Suka Makmur. Hasil dari pertemuan dengan bapak kepala desa beliau sangat mendukung kegiatan yang akan kami lakukan di desanya. Tim juga melakukan survey langsung kelokasi komunitas olahraga pencak silat yang berlatih di halaman mesjid lahmuddin, namun tim tidak bertemu dengan pengurus dikarenakan kegiatan latihan pencak silat 
dilaksanakan pada malam hari yaitu malam selasa, kamis dan sabtu. Dan pada tanggal 21 Juli malam sabtu tim kembali datang untuk melihat secara langsung proses latihan pencak silat yang dilakukan dan bertemu dengan bapak Pujiono dan Hermansyah selaku pelatih.

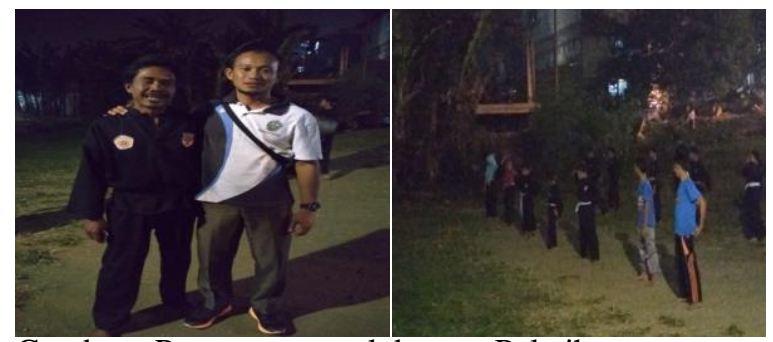

Gambar: Pertemuan awal dengan Pelatih

Kegiatan selanjutnya yang dilakukan oleh tim adalah memberikan penyuluhan bahaya narkoba yang dikalukan oleh dr. Miftahul Ihsan dan kegiatan pemberian motivasi dan tips-tips sukses menjadi atlet pencak silat yang di sampaikan oleh Rahmadayanti seorang atlet pencak silat Sumatera Utara peraih mendali perunggu PON Jabar 2016. Kegiatan ini dilakukan pada tanggal 25 Juli 2017 yang dihari oleh 35 orang siswa perguruan pencak silat Garuda Sakti. Kegiatan ini dilakukan disela sela latihan pencak silat.
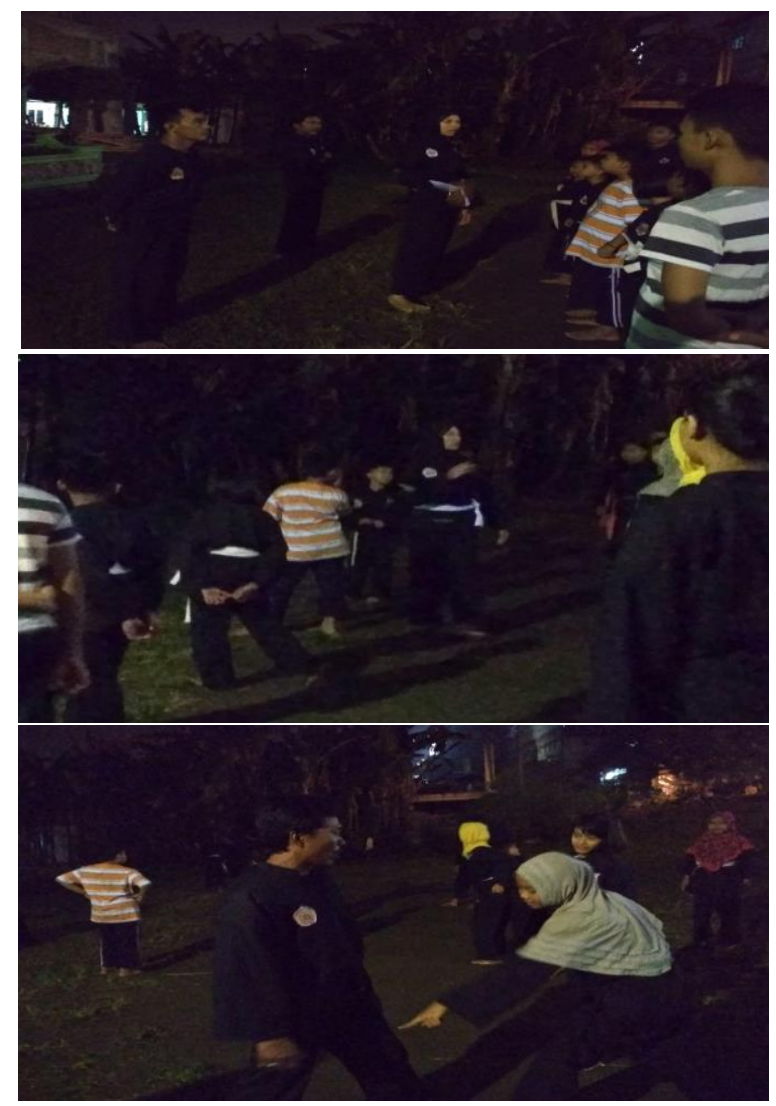

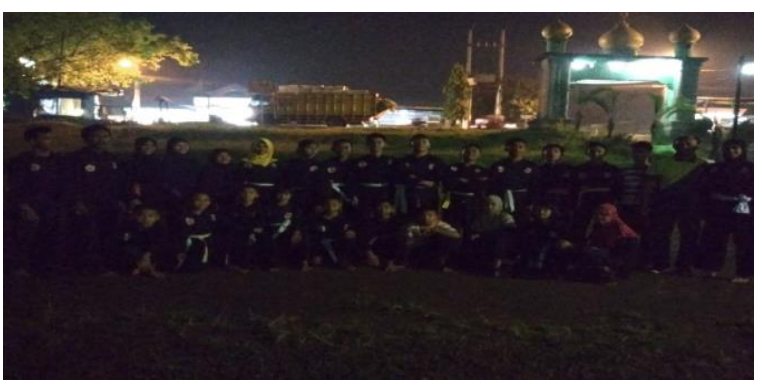

Gambar : Kegiatan Penyuluhan dan Coaching Clinic

Kegiatan berikutnya yang dilakukan oleh tim pengabdi adalah memberikan coching clinic dan pendampingan bagi pelatih dan siswa perguruan pencak silat yang dalam hal ini Rahmadayanti menjadi narasumber kegiatan ini. Kegiatan ini dilakukan sebanyak 4 kali pertemuan pada tanggal 1,3, 5 dan 8 Agustus 2017.

Diakhir kegiatan tim menyerahkan bantuan peralatan latihan berupa body protector sebanyak 6 pasang, petching 4 buah.
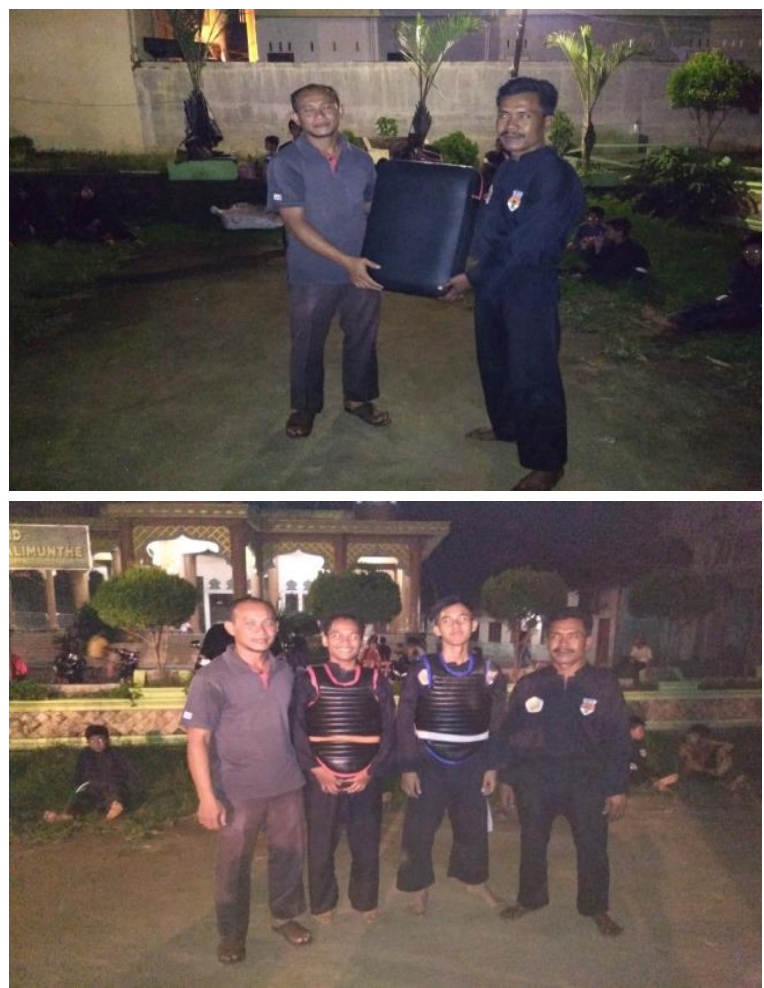

Gambar : Serah Terima alat

\section{KESIMPULAN}

Dengan adanya kegiatan pendampingan bagi komunitas olahraga yang ada di desa suka makmur, remaja siswa perguruan silat Garuda sakti menjadi lebih paham bahaya akan narkoba. sisiwa lebih termotivasi untuk terus berlatih dengan serius untuk menjadi atlet handal. Dengan adanya coaching clinic yang dilakukan pelatih juga memahami pentingnya penyusunan program latihan bagi peningkatan prestasi atlet binaannya. Bertambahnya fasiltas 
latihan yang dimilki oleh klub sehingga dapat membantu kelancaran proses latihan.

\section{SARAN}

Kegiatan yang sama hendaknya dapat dilakukan bagi komunitas komunitas olahraga lainnya, baik yang berada di Desa Suka Makmur, maupun desa lainnya. Sehingga kebermanfaatan ilmu pengetahuan yang dimiliki oleh prakktisi perguruan tinggi dapat bermanfaat bagi masyarakat luas.

\section{DAFTAR PUSTAKA}

DP2M Dikti (2013). Panduan Pelaksanaan Penelitian dan Pengabdian Masyarakat Perguruan Tinggi Edisi IX.

http://humas.polri.go.id/berita/Pages/Banyak--

Remaja--Terjerat Hukum. aspx. diakses tanggal 18 April 2016.

http://humas.polri.go.id/berita/Pages/BandarNarkoba-Manfaatkan-Remaja Jadi Kurir.aspx. diakses tanggal 18 April 2016.

http://www.jurnas.com/news/72091/TewaskanSiswa-Polri-Janji-Tindak-Tegas Pelajar Tawuran-2012/1/Sosial-Budaya/Humaniora), diakses tgl. 18 April 2016.

http://polrespurbalingga.com/stop-kenakalan-remajadan-pergaulan-bebas. diakses tanggal 18 April 2016.

http://www.okezone.com/berita/yuyun korban pemerkosaan dan pembunuhan. diakses tanggal 20 april 2016

Lutan, Rusli. 2013. Pedoman Perencanaan Pembinaan Olahraga. Asisten Deputi Penerapan IPTEK Keolahragaan. Bandung. PT. Remaja Rosdakarya.

Soekirman. 2015. Serdang Bedagai kampung Kami. Serdang Bedagai. PT. Bangun Bangsa Yogyakarta.

\section{Lampiran}

1. Body Protector

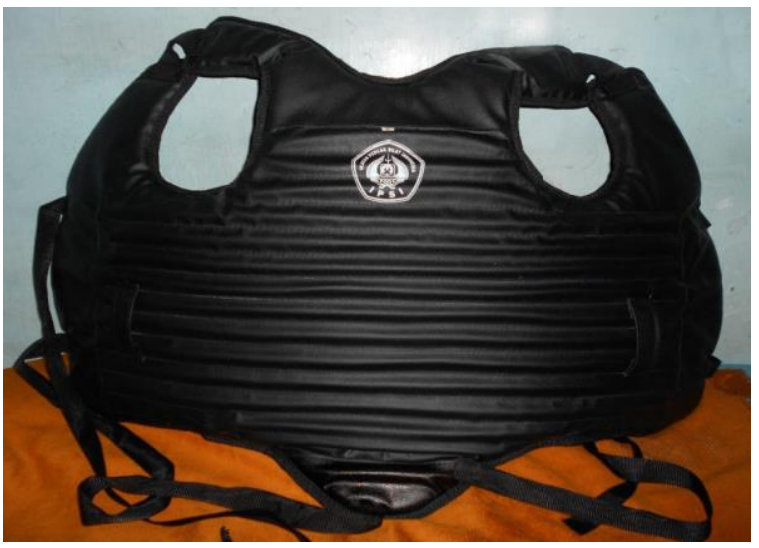

2. Target Tendangan dan pukulan

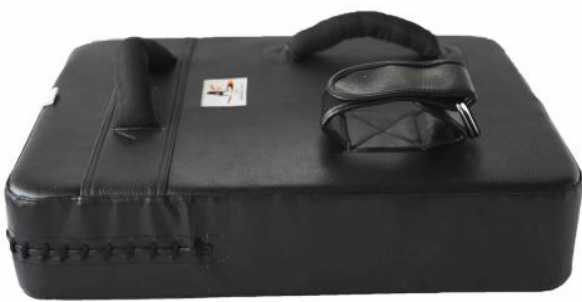

3. Target Pukulan

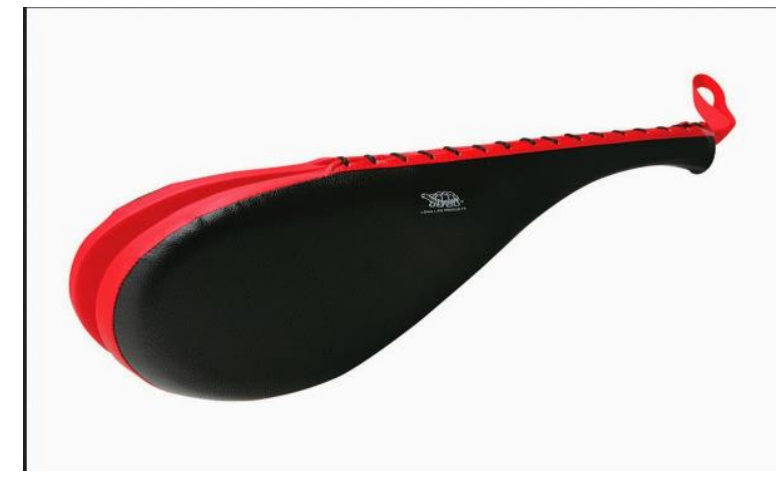

